\title{
УДК 579.62: 579.24:663.18
}

ТИНДИК В.С., tindiksaha.bz@ukr.net Державний науково-контрольний інститут біотехнологї $i$ итамів мікроорганізмів (ДНКІБШМ), м. Київ

\section{ЛІОФІЛІЗОВАНІ АЛОТРАСПЛАНТАНТИ, ЯК ЗАСОБИ ПІДГОТОВКИ СЕРЕДОВИЩ ДЛЯ КУЛЬТИВУВАННЯ МІКРООРГАНІЗМІВ}

Характеризуючи потребу мікроорганізмів в органічних джерелах слід відмітити, щзо найбільша ступінь гетеротрофності належить патогенним мікроорганізмам, щз пристосувались до життя людини та тварини. Перелік поживних середовищ для їх культивування особливо складний. Запропонований метод забезпечує відновлення біологічних якостей промислових штамів мікроорганізмів через використання природної бази їх паразитування (введення в склад поживних середовищ, розробленою тематикою ліофілізованих аллотрансплантантів) в визначених розробником кониентрачіях.

Ключові слова: сублімаційна сушка, ліофілізовані алотрансплантати, термічні гідролізати, панкреатичні гідролізати, амінний азот.

Вступ. Поживні середовища являються одним із основних компонентів мікробіологічних досліджень. Мікробіологія без поживних середовищ існувати не може, а їх якість визначає достовірність мікробіологічного аналізу. Кількість середовищ, що входять до складу регламенту на виготовлення середовищ (з врахуванням модифікацій) перевищує 5000 прописів. Мікробіологічна наука виникла одночасно з класичними дослідженнями Пастера та Коха. Особлива роль належить Роберту Коху.

Необхідність отримання чистої культури мікроорганізму, визначила створення умов для вирішення даного завдання. Найважливішим з якого є створення поживного середовища на якому можливо отримати ріст мікроорганізму.

Заслуга Коха грунтується на глибокому науковому підході до проблеми, а тому широкого використання поживних середовищ у власних дослідженнях. Ідеї та практична діяльність Коха отримали в кінці XIX століття та першої половини чверті XX століття інтенсивний розвиток. Саме в цей час, дослідники ряду країн запропонували поживні середовища різноманітного застосування, роль яких для практичної мікробіології є, i буде надзвичайною. Сучасний мікробіолог кожного дня в своїй роботі зустрічає їх імена.

Японець по походженню Ендо запропонував свій агар для диференціації ентеробактерій, австрієць Е. Левінштейн - середовище для мікобактерій, англієць А. МакКонкі селективне та диференціально-діагностичного середовища для кишкових мікроорганізмів, німець Кітт та італієць Д. Тароцці - середовище для збагачення анаеробних бактерій, француз Р. Сабуро та чех Ф.Чапек, американець А. Докс - середовища для грибів, бразилець Р. Хотінгер - середовіща широкого призначення на основі ферментативного перевару м'яса, та ін [1].

Надалі з особливою гостротою постало завдання стандартизації поживних середовищ, багато з яких містять недостатньо стандартні складові.

В зв'язку з цим, все більше заявляють про себе багатокомпонентні синтетичні поживні середовища запропоновані Гербертом (1961p.), і їх перелік неупинно зростає. 
На даний час, ринок пропонує широкий асортимент сухих поживних середовищ провідних світових фірм, але проблема якісних поживних середовищ залишається актуальною і ситуація має ряд негативних моментів, це недостатня стандартність багатьох поживних середовищ, а також не прозора сфера їх виробництва та контролю вихідного продукту.

Для процесів росту та розмноження мікроорганізми повинні отримувати всі речовини що потрібні для біосинтезу клітинних компонентів та отримання енергії. Ці речовини, що називаються поживними, повинні бути присутніми в культуральному (поживному) середовищі при цьому в кількості, що відповідає специфічним потребам мікроорганізму [2].

Поживні середовища мають виключне значення в мікробіології. Ретельний підбір складу середовища забезпечує можливість виділення мікроорганізмів, отримання чистих культур, вивчення їх морфологічних фізіологічних можливостей, ідентифікації, забезпечує швидку та правильну діагностику інфекційних патологій, підготовку ефективних біопрепаратів.

Якісний діапазон цих середовищ дуже широкий - від розчинів мінеральних солей на яких можуть рости автотрофи, до складних, що готуються з м'ясних гідролізатів, збагачених кров'ю або сироваткою, що використовуються для виділення і культивування особливо вибагливих мікроорганізмів, наприклад патогенних типу стрептококів, мікоплазм та ін.

Не дивлячись на присутність великої кількості середовищ, в нинішній час проводяться досліди по їх оптимізації та конструюванню нових на базі сучасних понять про метаболізм окремих видів мікроорганізмів, але універсальних середовищ для всіх мікроорганізмів не існує. Елементи котрі потрібні в першу чергу, необхідні для росту мікроорганізмів, що входять до складу поживного середовища, визначені хімічним складом мікробних клітин, котрий в природі загальний для всіх живих організмів.

Основною частиною загальної маси клітини є вода - 80-90\% і тільки 10-20\% припадає на суху речовину. По кількісному складу в сухій речовині виділяють макро - і мікроелементи. До макроелементів відносять вуглець, кисень, азот, водень, сірку, фосфор, калій, натрій, магній, кальцій та залізо.

До мікроелементів - марганець, молібден, цинк, мідь, кобальт, та інші, більшість 3 яких присутні в дуже незначних кількостях. Більшість мікроорганізмів, в тому числі і патогенних мають тип живлення при якому джерелом вуглецю, енергії і донором електронів є органічні речовини.

Характеризуючи потребу мікроорганізмів в органічних джерелах вуглецю слід відмітити, що найбільша ступінь гетеротрофності належить патогенним мікроорганізмам, що пристосувались до життя в організмі людини та тварини. Перелік поживних середовищ для їх культивування особливо складний. Такі середовища в своєму складі вміщують білки або продукти їх неглибокого гідролізу (пептиди), вітаміни, фрагменти нуклеїнових кислот та інше.

Для конструювання таких середовищ використовують різного роду гідролізати, екстракти, м'ясо або сироватку, дріжджові та рослинні екстракти та багато іншого. Такі середовища придатні для культивування найрізноманітніших видів мікроорганізмів, i особливо придатні в тих випадках, коли невідома потреба мікроорганізму в факторах росту або він вимагає присутності великої кількості факторів росту одночасно. Недоліком таких середовищ $\epsilon$ складність або неможливість досягнення їх стандартизації та обмеженому контролі якості вихідної сировини [3].

Ліофілізація (ліофільна сушка, сублімаційна сушка) - метод висушування біологічних об'єктів і харчових продуктів в замороженому стані у вакуумі [4]. При цьому, в процесі вода видаляється 3 замороженого матеріалу шляхом випаровування, минаючи рідку фазу. 
Ліофілізація широко застосовується в ветеринарній, біологічній практиці та харчовій промисловості для довготривалого зберігання мікроорганізмів, діагностичних, та лікарських біопрепаратів, а також тваринних та рослинних тканин та продуктів [5]. При ліофілізації вода 3 об’єктів видаляється без порушення нативної структури білків, в них різко зупиняються біохімічні реакції, в результаті чого вони стають більш стійкими до впливу факторів зовнішнього середовища, та зберігають натуральну структуру на протязі тривалого часу зберігання. Даний факт практично опрацьований в лабораторній роботі на протязі ії виконання.

В результаті сублімації не зв'язана вода вивільняється з маси замороженого матеріалу, препарат переходить 3 твердого стану (замороженого) в сухий (пориста маса, що майже не міняється в об'єм і) [6].

В дослідах моєї роботи якість і доцільність перспективи досліду ліофілізації матеріалів оцінюється наступними показниками:

1. Форма і положення ліофілізату у флаконі.

2. \% вологості в матеріалі.

3. Структура ліофілізоваого матеріалу (гістологія, мікроскопія).

4. Рівень $\mathrm{pH}$ показника матеріалу у водному розчині (зміна $\mathrm{pH}$ контрольного розчину).

5. Амінний азот (кількість) в розчині.

6. Біологічна активність (ростові якості) по відношенню до мікроорганізмів.

Для успішного виконання досліду потрібен правильно відібраний матеріал. Перевагами мого методу $є$ те, що матеріал відібраний у вигляді алотрансплантантів підготовлений по даній методиці є природно нативним матеріалом для роботи 3 мікроорганізмами, який можливо закладати на довгострокове зберігання в ліофілізованому вигляді [7].

\section{Відбір експериментальних моделей алотрансплантантів для сублімації}

\begin{tabular}{|l|l|l|}
\hline$№$ п/п & Об’єкт для сублімації & Назва хвороби \\
\hline 1. & Головний мозок тварин та птиці & Мікоплазмоз лістерія \\
\hline 2. & Легені тварин і птиці & Туберкульоз, пастерельоз \\
\hline 3. & Печінка (ВРХ, свині, птиця) & $\begin{array}{l}\text { Бешиха кампілобактеріоз, сальмонельоз, анаеробні } \\
\text { інфекції, сибірська виразка }\end{array}$ \\
\hline 4. & Селезінка (ВРХ, свині, птиця) & Пастерильоз, лістеріоз, бешиха, сибірська виразка \\
\hline 5. & $\begin{array}{l}\text { М’язева тканина (ВРХ, свині, } \\
\text { птиця) }\end{array}$ & $\begin{array}{l}\text { Бешиха кампілобактеріоз, сальмонельоз, анаеробні } \\
\text { інфекції, сибірська виразка }\end{array}$ \\
\hline 6. & Дерма (ВРХ, свині) & Бешиха, тріхофітія, ікроспорія, \\
\hline
\end{tabular}

Підготовка середовищ.

В даний час для виготовлення середовищ використовуються технології:

а) термічних гідролізатів;

б) панкреатичних - термічних гідролізатів;

в) а в випадку мого дослідження, використовувалась розроблена методика отримання холодних гідролізатів через використання сублімаційного обладнання (авторська формула).

Технологія виготовлення середовищ зводиться до обробки природних ліофілізованих тканин органів тваринного організму в водних розчинах та відокремленню низько- 
молекулярних від високомолекулярних білків в технологічному процесі підготовки водних розчинів низькомолекулярних білків для підготовки поживних середовищ.

Використання промислових штамів мікроорганізмів для виробництва біологічних препаратів потребує специфічного підходу для робіт по відновленню їх біологічної природи. Здебільшого це культури інфекційних патологій промислових тварин та птиці, відновлення яких строго потребує використання біологічної основи, тобто макроорганізму на якому в природі паразитує дана патологія.

Запропонований метод забезпечить відновлення біологічних якостей промислових штамів через використання природної бази їх паразитування, (введення іï в склад поживних середовищ, розроблених даною тематикою препаратів) в визначених розробником концентраціях.

В результаті контакту штаму 3 ліофілізованим алотрансплантантом мікроорганізм отримав типові для даного виду мікроорганізмів властивості :

- морфологічні, біологічні, серологічні;

- стабільність біологічних характеристик під час пасажувань;

- підвищення ступеню вірулентності та імуногенності до сприйнятливих лабораторних моделей чи сприйнятливих сільськогосподарських тварин за показником ЛД50 для контрольних штамів та ІД50 для вакцинних штамів;

- здатності дисемінації в макроорганізмі органотрофності та шляхам елімінації;

- генетичних особливостей штаму.

Мета роботи. Отримання засобів (джерел) стимуляції ростових якостей виробничих штамів мікроорганізмів через використання сублімаційного обладнання.

Матеріали і методи досліджень. Готуємо по 10 флаконів потрібного матеріалу. Отриманий матеріал у пеніцилінових флаконах покриваємо спеціальними гумовими корками (стерильними).

Роботи виконуємо в умовах боксу. Отриманий матеріал розміщуємо в морозильну камеру на 24 години при температурі мінус 60 - 80 град. Цельсія. Далі матеріал після глибокого заморожування в камері глибокого заморожування швидко переносимо до субліматора не допускаючи процесу придонного розморожування. Отриманий в результаті сублімації матеріал в умовах субліматора герметично закриваємо прес-полицями та укупорюємо алюмінієвими ковпачками після виймання з субліматора.

Вивчаємо отриманий ліофілізований матеріал на присутність структурних змін в результаті сублімації (мікроскопія, гістологія, бактеріологія (висів на середовища)).

Результати досліджень та їх обговорення. В результаті сублімації паренхіматозних тканин отримано:

- компактний екземпляр сублімованої тканини паренхіматозних органів, що вільно переміщається у геметизованому флаконі при струшуванні.

В результаті досліду сублімації матеріалу, незв'язана вода вивільнилась 3 маси замороженого матеріалу (дослід визначення маси вивільнення вологи та отримана пориста маса, що майже не змінилась в об’ємі). Процес розмелювання ліофілізату після сублімації пройшов з позитивним результатом (після розмелювання отримано суху гомогенну масу). Процент вологи на момент визначення досягав 2,7\%. Ліофілізат набув характерної структури, що властива ліофілизату, тобто його фіброархітектоніка значно відрізняється від нативного зразка не ліофілизованої тканини. Алотрансплантант набув виражених структурних перетворень (мікроскопія). Пучки колагенових волокон розташовані окремими фрагментами, 3 визначеними тінкторіальними властивостями, що свідчить про їх часткову деструкцію. Розмір 
міжпучкових просторів коливається в межах від 20 до 50 мікронів. Солітарні пучки набули виду рихлої сітки, частини якої чергуються, невеликими фрагментами щільних пучків колагенових волокон,

Таким чином, в результаті проведеної роботи отримано дані, що вказують на харктер та вираженість структурних змін в міжклітинних просторах які проходять після ліофілізації i залежать від ступеню гідративності аморфного матрикса, а також від специфічності фіброархітектоніки тканини, про що свідчить також інформація літературних даних.

рН-визначався у водному розчині дистильованої води та ліофілізату

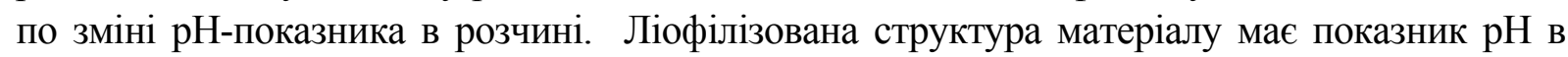
розчині близький до нейтрального $(7,0)$. Амінний азот досягав позначки 900 млгр/\% +।200 млгр $\ \%$ залежно від якості тканини.

Біологічну активність вивчали в прямому контакті з ліофілізатом,

тобто на пластинку агару Red phenol agar фірми Himedia в чашках Петрі після нанесення 17 годинної культури Ісаченко, застосували прямий контакт ліофілізату 3 культурою, що була нанесена на агарову пластинку середовища раніше (Метод адсорбції. Поглинання поверхнею твердого тіла). Паралельно був проведений засів на теж середовище Red phenol agar

без нанесення ліофілізату. При підрахунку кількості колоній в обох засівах виявлено: 3 внесеним ліофілізатом - 100 колоній, а без внесення ліофілізату - 10 колоній.

При постановці біологічної проби на предмет патогенної активності культури Ісаченко, що була отримана в присутності ліофілізату та без застосування ліофілізату встановлено наступне:

В результаті проведених дослідів встановлено:

- застосування прямого контакту ліофілизату методом адсорбції на середовищі призвело до підвищення активності росту культури Ісаченка в 10 разів; - патогенна активність культури отриманої на середовищах з використанням ліофілізату була на 60 \% вища.

Таблиия 2

\section{Патогенна активність культури Ісаченко для білих мишей в присутності ліофілізату та без ліофілізату}

\begin{tabular}{|l|c|c|c|}
\hline & Інфіковано & Загинуло & \% від заг числа \\
\hline $\begin{array}{l}\text { Патогенність 3 внесеним } \\
\text { гідролизатом }\end{array}$ & 10 & 9 & 90 \\
\hline $\begin{array}{l}\text { Патогенність без внесення } \\
\text { гідролізату }\end{array}$ & 10 & 3 & 30 \\
\hline
\end{tabular}

Висновки та перспективи подальших досліджень. Отримання низькомолекулярних білків з використанням методу екстракції, сорбції та електрофорезу ліофілізатів є методом ефективного отримання ростових стимуляторів для мікроорганізмів, що немає аналогів в ветеринарній лабораторній практиці.

При постановці методу на виробничу основу та подальшого вивчення напрямку він може стати високоефективним шляхом для отримання конкурентних вітчизняних середовищ для культивування мікроорганізмів. 


\section{СПИСОК ЛІТЕРАТУРИ}

1. Методы общей бактериологии [Текст] : В 3-х т.: Пер. с англ. Т. 1 / Под ред. Ф. Герхарда. М.: Мир, 1983. - 536 с.

2. Готтшалк Г. Метаболизм бактерий. - М.: Мир, 1982. - 310 с.

3. Питательные среды для медицинской и санитарной микробиологии./ Поляк М.С., Сухаревич В.И., Сухаревич М.Э.- СПб.: ЭЛБИ-СПб. - 2008. - 352 с.

4. Ciurzyńska A. Freeze-Drying - Application in Food Processing and Biotechnology - A Review / A. Ciurzyńska , A. Lenart // Pol. J. Food Nutr. Sci., 2011.- Vol. 61, №. 3.- pp. 165-171

5. Ozkavukcu S. Cryopreservation: Basic knowledge and biophysical effects// Journal of Ankara medical school. - 2002. - Vol. 24. - No. 4. - P. 187-196.

6. Rowe, T.W.G. Freeze-drying of biological materials: some physical and engineering aspects// Current Trends in Cryobiology. - 1970. - P. 61-138.

7. Лебедев Д.П. Теплометрические основы оптимизации параметров сублимационной сушки в вакууме/ Лебедев Д.П., Геращенко О.А., Андреев Е.Ф. - ИФЖ. - 1973. - Т.24, № 6. С. 1059-1064.

\section{ЛИОФИЛИЗИРОВАННЫЕ АЛОТРАСПЛАНТАНТЫ, КАК СРЕДСТВА ПОДГОТОВКИ СРЕДЫ ДЛЯ КУЛЬТИВИРОВАНИЯ МИКРООРГАНИЗМОВ / ТЫНдЫК В.С.}

Характеризуя потребность микроорганизмов в органических источниках следует отметить, что наибольшая степень гетеротрофности присуща патогенным микроорганизмам приспособившимся к жизни человека и животного. Состав питательных сред для их культивирования особенно сложен.

Предложенный метод обеспечивает восстановление биологических свойств микроорганизмов через использование природной базы их паразитирования (путем введения в состав питательных сред разработанной данной тематикой лиофилизированых аллотрансплантантов) в определенных разработчиком концентрациях.

\section{FREEZE-DRYING ALOTRASPLANTANT AS A MEANS OF PREPARATION OF THE ENVIRONMENT FOR CULTIVATION OF MICROORGANISMS / Tyndyk VS}

Introduction. The nutrient medium is one of the main components of the microbiological studies.

Lyophilisation (loflin drying, freeze-drying) - drying method of biological objects and food products in a frozen state in a vacuum.

The advantages of my method is that the material selected in the form allotransplantata prepared by this method is of course the native material.to work with microorganisms.

The developed method of obtaining cold hydrolysates through the use of sublimation equipment.

The technology of manufacturing environments is only to process natural freeze-dried tissues of animal organs of the body.

The goal of our work. Receipt of tool (sources) stimulation of the growth qualities of the production strains of microorganisms through the use of sublimation equipment.

Materials and methods research. Work is performed in terms of Boxing. The resulting material is placed in the freezer for 24 hours at a temperature of minus 60 - 80 degrees. Celsius.

Results of research and discussion. As a result of the sublimation of parenchymal tissue received:

- compact instance of freeze-dried tissue of the parenchymatous organs, moves freely in gematitovogo the bottle when shaken. Biological activity was studied in direct contact with laflaca,

In the formulation of a biological sample on the subject of the pathogenic activity of culture Isachenko, which was obtained in the presence of laflat and without the use of laflat established the following: the use of direct contact lovelytata by adsorption on the environment has led to increased growth activity of the culture. 
Conclusions and prospects for further research. The preparation of low molecular weight proteins using the method of extraction, sorption and electrophoresis laflat is a method of efficiently producing a growth stimulant for microorganisms that has no analogues in veterinary laboratory practice.

Key words: freeze drying, freeze-dried allografts, thermal hydrolysates, pancreatic ydrolysates, AMNI nitrogen.

\section{REFERENCES}

1. Gerhard F. (1983) Metody obshhej bakteryologyy [Methods of General Microbiology]: (Vols 1-3). M.: Myr [in Russian].

2. Gottshalk G. (1982) Metabolyzm bakteryj [Metabolism of bacteria]. — M.: Myr [in Russian].

3. Poljak M.S., Suharevych V.Y., Suharevych M.Э. (2008) Pytatel'nble sredbl dlja medycynskoj y sanytarnoj mykrobyologyy [Nutrient media for medical and sanitary microbiology]. SPb.: ЭLBY-SPb. [in Russian].

4. Ciurzyńska A., Lenart A. (2011) Freeze-Drying - Application in Food Processing and Biotechnology - A Review. Pol. J. Food Nutr. Sci., Vol. 61, 3, 165-171 [in English].

5. Ozkavukcu S. (2002) Cryopreservation: Basic knowledge and biophysical effects. Journal of Ankara medical school., Vol. 24., 4, 187-196 [in English].

6. Rome, T. G. W. (1970) Freeze-drying of biological materials: some physical and engineering aspects. Current Trends in Cryobiology., p. 61-138 [in English].

7. Lebedev D. P., Gerashchenko O. A., Andreev E. F. (1973) Teplometricheskie osnovy optimizacii parametrov sublimacionnoj sushki $\mathrm{v}$ vakuume [Thermometric bases of optimization of parameters of sublimation drying in vacuum]. IFZh., Vol. 24, 6, 1059-1064 [in Russian].

\section{УДК 619:616.98:578.27:636.2}

ФОТІНА Г.А., д-р вет.наук, професор, super.annafotina@ukr.net, TIOH М.Т., аспірант

Сумський національний аграрний університет

\section{ФАРМАКО-ТОКСИКОЛОГІЧНІ ВЛАСТИВОСТІ ABRUS PRЕСАTORIUS}

В статті наведені дані по визначенню середньо летальної дози $\left(L D_{50}\right)$, гематологічний та біохімічний вплив різних екстрактів насіння Abrus precatorius на організм лабораторних мишей. Аналіз визначення складових частин показав наявність вмісту вологи, золи, сирого протеїну, та вміст сирої клітковини, в той час як вміст вуглеводів оцінювали шляхом віднімання значень, отриманих для жирів i білків з органічної речовини. Фітохімічний скринінг показав наявність алкалоїдів, флавоноїдів, дубильних речовин, сапонінів і редукуючи иукрів в обох, етиловому $і$ метанольному екстрактах. Насіннєві екстракти Abrus precatorius можуть бути використані як кроветворний засіб, іммуносупрессор, гіпохолестерінемічний і ренотоксичний засіб.

Ключові слова: фіто хімічний скринінг, насіння Abrus precatorius, імунодепресанти, кровотворний засіб, гіпохолестерінемічний засіб, ренотоксичність.

Вступ. Природа є джерелом лікарських засобів протягом тисяч років, і одна чверть сучасних ліків, були виділені з природних джерел [1]. Традиційні системи медицини на рослинній основі продовжують відігравати важливу роль в охороні здоров'я, при цьому 